\title{
NAMES OF HISTORICAL GEOGRAPHICAL PLACES AND ARTICLES USED WITH THEM
}

The paper analyses the use of articles with the names of historical geographical places and related issues (focused on prehistoric and ancient times) in the English language. The paper is divided into three parts. The first one summarizes general rules for the use of articles with geographical names in prescriptive English grammar books. The second part contains a table which aims to present the list of the historical geographical names with corresponding articles. The final one concentrates on the analysis of the actual use of articles with the historical geographical names as found in the following books on history: The Concise History Encyclopaedia and The Western Experience.

\section{Introduction}

Generally, the functioning of articles in the English language is far from being clear. As for geographical names, the rules for the use of articles with these lexemes have been summarized and are easy to be found in any book on English grammar. Nevertheless, the use of articles with historical geographical place names is the area which has not been covered yet. Due to the large amount of the gathered material, we were bound to concentrate only on two historical periods - prehistoric and ancient times.

\section{Various approaches to the use of articles with geographical names}

Studying the essential prescriptive grammars of the English language we have found the following information:

The Heinemann ELT English Grammar (1998, p. 172) suggests the zero article for the following geographical names: continents (Africa); countries, states, departments (England, California, Hampshire); cities, towns, villages (Sydney, Bilbao); individual islands (Crete); lakes (Lake Geneva); individual mountains (Mount Fuji) and streets (Oxford Street). However, the definite article is introduced for: countries and states when they include a countable noun (the Federal Republic of Germany); plural place names (the West Indies) and for names such as the Arctic, the Antarctic, the Far East, the Costa Brava.

The definite article is to be used with the names of oceans, seas (the Pacific); rivers (the Mississippi); canals (the Panama Canal); deserts (the Sahara); island groups (the Canaries); hotels, cinemas (the Plaza Hotel, the Cannon Cinema); museums, clubs (the Prado Museum, the Black Cat Club) and restaurants, pubs (the Hard Rock Café).
Names of hotels, restaurants named after the people who started them + the possessive's (Marcy's Hotel) and churches named after saints + the possessive's (St Peter's Church) represent the exceptions to the above mentioned rule.

According to Murphy (1989, p. 148), the definite article is obligatory also in these instances: mountain ranges (the Rocky Mountains, the Rockies); galleries (the National Gallery); bridges (the Golden Gate Bridge) and cardinal points (the north of Mexico).

Moreover, articles are not applied in the following geographical names: roads, squares, parks (North Road, Time Square, Central Park) and names of important buildings and institutions when the first word is the name of a person or a place (Lincoln Centre).

Eastwood (1994, p. 210) introduces the definite article in these cases: the Gambia, the Ukraine, the Matterhorn, the Eiger, the Hague, the Bronx, the Mall, the Strand and also for the names of by-passes, motorways (the York by-pass, the M6). The definite article is not placed before the names of most bridges (Westminster Bridge). If the name is premodified by an adjective, the definite article is to be used (the Royal Opera House).

Swan (2005, p. 65) recommends the zero article when a title of the principal public building and organization of a town begins with the town name (Salisbury Cathedral). However, the usage varies with the names of less important institutions ((the) Newbury School of English).

Longman English Grammar (1998, p. 70) contributes with these extra exceptions: the Jungfrau (mountain); Death Valley (the name of a valley without the definite article); the Argentine, Argentina, (the) Sudan, (the) Yemen (countries).

At the same time, this is the only book where the use of articles with some historical references is mentioned: Ancient Greece,

\footnotetext{
* Marta Kadorova, Zuzana Ondrackova

Department of English Language and Literature, Faculty of Science, University of Zilina, Slovakia, E-mail: marta.kadorova@fpv.uniza.sk, zuzana.ondrackova@fpv.uniza.sk
} 
Medieval Europe, Pre-war/Post-war Germany, Roman Britain (all of them used with the zero article); the Dark Ages, the Renaissance, the Stone Age (all of them used with the definite article).

According to A Comprehensive Grammar of the English Language (1985, p. 293), the definite article is suggested for these exceptions: the Great Salt Lake, the Bodleian (Library); the City, The West / East End (of London);

The usage of the definite and indefinite article alternates in the following instances: (the) Argentine, (the) Ukraine, (the) Sinai, (the) Bosphorus.

The definite article is the only acceptable option with the names of other geographical names of coastline (the Gulf of Mexico, the Cape of Good Hope, the Bay of Biscay, the Strait of Magellan, the
Sound of Bute, the Isle of Man, the Isle of Wight) and with the names of regions (the Crimea, the Saar, the Punjab, the Ruhrthe (Deep) South, the Midwest).

\section{The use of articles with the analysed geographical names and related issues}

The table below aims to present the list of geographical names and related issues covering two historical periods - prehistoric and ancient times as found in the following books: The Concise History Encyclopaedia and The Western Experience. Articles with individual geographical names and related issues, as they occurred in the analysed texts, have been included, as well. The geographical names are classified according to their reference in the given books.

\section{Empires}

\begin{tabular}{|l|l|l|l|}
\hline the Persian Empire & the Egyptian Empire & an Athenian empire & the western Roman empire \\
the Persian empire & the Roman Empire & the Athenian Empire & the Eastern Empire \\
a Persian empire & the Empire & $\begin{array}{l}\text { Mediterranean empire } \\
\text { the Mauryan Empire }\end{array}$ & $\begin{array}{l}\text { early Rome } \\
\text { the Great Babylonian Empire } \\
\text { the Holy Roman Empire } \\
\text { the late Roman Empire } \\
\text { the Assyrian Empire }\end{array}$ \\
the Western Empire & Gubta empire \\
\hline
\end{tabular}

\section{Kingdoms}

\begin{tabular}{|c|c|c|}
\hline $\begin{array}{l}\text { the Akkadian kingdom } \\
\text { Ebla as an independent kingdom } \\
\text { the Babylonian Kingdom } \\
\text { the kingdom of Babylon } \\
\text { Babylon } \\
\text { the kingdom of Egypt } \\
\text { Early Egypt } \\
\text { Upper Egypt } \\
\text { Lower Egypt } \\
\text { the Old Kingdom } \\
\text { the New Kingdom } \\
\text { the Middle Kingdom }\end{array}$ & $\begin{array}{l}\text { kingdom of the Hittites } \\
\text { the Egyptian kingdom } \\
\text { the Hittite kingdom } \\
\text { the Hittite Kingdom } \\
\text { the great kingdom of the ancient Near } \\
\text { East } \\
\text { the Israelite kingdom of antiquity } \\
\text { the Kingdom of the Medes } \\
\text { the Chaldean Kingdom } \\
\text { Oriental kingdoms } \\
\text { the Eastern kingdom } \\
\text { the kingdom of Macedonia } \\
\text { Saxon England }\end{array}$ & $\begin{array}{l}\text { the Seleucid kingdom } \\
\text { Macedonian monarchy } \\
\text { the kingdom of Pergamum } \\
\text { the kingdom of Pontus } \\
\text { the Parthian kingdom } \\
\text { the kingdom of Kush } \\
\text { Nubian kingdom of Kush } \\
\text { the strong kingdom of Mari } \\
\text { Maghada } \\
\text { The kingdom of Axum } \\
\text { Middle Kingdom (China) } \\
\text { Germanic kingdoms }\end{array}$ \\
\hline
\end{tabular}

\section{Empires}

\begin{tabular}{|l|l|l|l|}
\hline States & Media & the Athenian state & the state of Zhou \\
Turkey & Lydia & the Roman Republic & united imperial China \\
Iraq & Greece & the Republic & Han China \\
Syria & classical Greece & the Roman state & Gubta India \\
Palestine & the Dorian states & Roman Italy & Roman Britain \\
Ethiopia & the Greek states & Jordan & classical Japan \\
the modern state of Israel & Sparta & the ancient China & Assyrian state \\
Phoenicia & Macedonia & Bavaria & \\
Persia & & Iberia & \\
\hline
\end{tabular}


Cities, towns \& villages

\begin{tabular}{|l|l|l|l|}
\hline Jericho, the city of Jericho & Niniveh & Pompeii & the city of Tiahuanaco \\
Jerusalem & Persepolis & Damascus & Chalcis \\
Jarmo & Knossos & the town of Sinope & Miletos \\
Uruk & Mycenae & Constantinople & Smyrna \\
Aleppo & Troy & Harappa & Eretria \\
the city of Ebla & Olympia & Mohenjo-daro & Cyrenaica \\
Babylon & Byzantium & Anyang & Marathon \\
Athens, the city of Athens & the city of Byzantium & Ur & Niani \\
Memphis & Corinth & Elam & Yelwa \\
Giza & Miletus & Anyang & Maghada \\
the city of Cairo & the city of Miletus & Isin & Ajanta \\
Cairo & the village of Plataea & Elam & Nalianda \\
Thebes & the town of Potidaea & Napata & Heian \\
Akhetaton & Syracuse & Meroë & Nara \\
Karnak & the polis of Thebes & Jenne-jeno & Izumo \\
Kadesh & the city of Alexandria & Laventa & Tikal \\
Hattuska & the city of Pergamum & the city of Babylon & Palenque \\
Carthage & the village of Cumae & Tarquinia & Yaxchilán \\
Canaan & the city of Messana & Judah & Copán \\
the town of Sheckem & the village of Pidna & Tyre & Calakmul \\
the city of Ashur & the town of Pharsalus & Ecbatana & El Mirador \\
Sparta & Ephesus & the city of Teotihuacán & \\
Delphi Sardis & Antioch & & \\
\hline
\end{tabular}

Valleys

\begin{tabular}{|l|l|l|l|}
\hline $\begin{array}{l}\text { the Indus Valley } \\
\text { the Nile Valley }\end{array}$ & $\begin{array}{l}\text { the valley of the upper Tigris } \\
\text { River } \\
\text { the Valley of the Kings }\end{array}$ & $\begin{array}{l}\text { the rich Po valley } \\
\text { the Tigris-Euphrates Valley }\end{array}$ & the Danube valley \\
\hline
\end{tabular}

\section{Mountain ranges}

\begin{tabular}{|l|l|l|}
\hline the Taurus Mountains & the Apennine range & the Hindu Kush mountains
\end{tabular}

Mountains \& hills

\begin{tabular}{|l|l|l|l|l|}
\hline Tell Mardikh & Mount Sinai & Mount Olympus & the Pnyx & Mount Ilopango \\
\hline
\end{tabular}

Rivers

\begin{tabular}{|l|l|l|l|l|}
\hline $\begin{array}{l}\text { the Tigris } \\
\text { the Tigris River } \\
\text { the upper Tigris River } \\
\text { the Euphrates } \\
\text { the Euphrates River }\end{array}$ & $\begin{array}{l}\text { the Nile } \\
\text { the Nile River } \\
\text { the White Nile } \\
\text { the Blue Nile }\end{array}$ & $\begin{array}{l}\text { the Indus } \\
\text { the Indus River } \\
\text { the Jordan River } \\
\text { the Halys River }\end{array}$ & $\begin{array}{l}\text { the Po River } \\
\text { the Tiber River } \\
\text { the Tiber } \\
\text { the Rubicon River }\end{array}$ & $\begin{array}{l}\text { the upper Yellow River } \\
\text { the Rhine River } \\
\text { the Danube River }\end{array}$ \\
\hline
\end{tabular}

Seas

\begin{tabular}{|l|l|l|l|l|}
\hline $\begin{array}{l}\text { the Mediterranean } \\
\text { the Mediterranean Sea }\end{array}$ & $\begin{array}{l}\text { the Red Sea } \\
\text { the Aegean Sea }\end{array}$ & $\begin{array}{l}\text { the Aegean } \\
\text { the Black Sea }\end{array}$ & the Dead Sea & the Adriatic Sea \\
\hline
\end{tabular}




\section{Deltas}

the Mekong delta

Regions

\begin{tabular}{|c|c|c|c|}
\hline $\begin{array}{l}\text { Asia Minor } \\
\text { western Asia Minor } \\
\text { the entire Near East } \\
\text { the ancient Near East } \\
\text { Anatolia } \\
\text { central Anatolia } \\
\text { the region of Akkad, Akkad } \\
\text { the region of Syria } \\
\text { Ebla's territory } \\
\text { the Near East } \\
\text { Mesopotamia } \\
\text { the Fertile Crescent } \\
\text { the European mainland }\end{array}$ & $\begin{array}{l}\text { the Delta } \\
\text { Punt, a territory } \\
\text { the Balkan areas } \\
\text { Ionia, the region of Ionia } \\
\text { the territory of Messenia } \\
\text { Etruria } \\
\text { Illyria } \\
\text { Achaea } \\
\text { Nearer Spain } \\
\text { Farther Spain } \\
\text { Cilicia } \\
\text { the Assyrian lands }\end{array}$ & $\begin{array}{l}\text { Bithynia } \\
\text { Thessaly } \\
\text { the Roman province } \\
\text { of Britain } \\
\text { Gaul } \\
\text { Judea } \\
\text { the Middle East } \\
\text { Siberia } \\
\text { Brittany } \\
\text { Alaska } \\
\text { the Levant } \\
\text { Alaca }\end{array}$ & $\begin{array}{l}\text { the Hittite territories } \\
\text { northern Arabia } \\
\text { the Israelite territories } \\
\text { Nubia } \\
\text { Arabia } \\
\text { the Tasili area } \\
\text { the Bantu } \\
\text { Nok } \\
\text { Axum } \\
\text { Bactria } \\
\text { southern Mesopotamia } \\
\text { northern Mesopotamia }\end{array}$ \\
\hline
\end{tabular}

\section{Buildings \& monuments}

\begin{tabular}{|c|c|c|}
\hline $\begin{array}{l}\text { the Acropolis } \\
\text { the Athenian Acropolis } \\
\text { the Aswam Dam } \\
\text { the Tower of Babel } \\
\text { Bel, the Tower of Babel } \\
\text { the Great Pyramid } \\
\text { the Step Pyramid of Zoser } \\
\text { the pyramid of Khefre } \\
\text { the Temple in Jerusalem }\end{array}$ & $\begin{array}{l}\text { the Wailing Wall } \\
\text { the Hanging Gardens } \\
\text { the Hall of a Hundred Columns } \\
\text { the Palace of Minos } \\
\text { the mighty Gate of the Lionesses/ } \\
\text { the Lion Gate } \\
\text { the Parthenon } \\
\text { the Colosseum } \\
\text { the Valley Temple }\end{array}$ & $\begin{array}{l}\text { the Great Bath } \\
\text { the walls of Jericho } \\
\text { the temple of Marduk } \\
\text { the Great Wall } \\
\text { the Western Wall } \\
\text { the ancient fortress of Masada } \\
\text { the Shinto Kasuga Shrine }\end{array}$ \\
\hline
\end{tabular}

Nationalities \& tribes

\begin{tabular}{|c|c|c|c|}
\hline $\begin{array}{l}\text { the Aztecs } \\
\text { the Mayas } \\
\text { the Sumerians } \\
\text { the Semits } \\
\text { the Eblaites } \\
\text { the Mesopotamians } \\
\text { the Babylonians } \\
\text { the Egyptians } \\
\text { the Macedonians }\end{array}$ & $\begin{array}{l}\text { the Asiatics } \\
\text { the Israelites } \\
\text { the Hittites } \\
\text { the early Indo-Europeans } \\
\text { modern Jews } \\
\text { the Canaamites } \\
\text { the Phoenicians } \\
\text { the Philistines } \\
\text { the Assyrians } \\
\text { the Romans }\end{array}$ & $\begin{array}{l}\text { the Jews } \\
\text { the Greeks } \\
\text { the Chaldeans } \\
\text { the Iranians } \\
\text { the Medes } \\
\text { the Melians } \\
\text { the Persians } \\
\text { the Minoans } \\
\text { the Trojans } \\
\text { the Dorians }\end{array}$ & $\begin{array}{l}\text { the Etruscans } \\
\text { the Athenians } \\
\text { the Messenians } \\
\text { the Spartans } \\
\text { the Corintians } \\
\text { the Romans } \\
\text { the Apennines } \\
\text { Celtic peoples known as Gauls } \\
\text { the Gauls }\end{array}$ \\
\hline
\end{tabular}

Continents

\begin{tabular}{|l|l|l|l|}
\hline $\begin{array}{l}\text { east Africa } \\
\text { East Africa }\end{array}$ & $\begin{array}{l}\text { central Africa } \\
\text { western Asia }\end{array}$ & $\begin{array}{l}\text { central Asia } \\
\text { Central America }\end{array}$ & $\begin{array}{l}\text { southeast Europe } \\
\text { negro west Africa }\end{array}$ \\
\hline
\end{tabular}


Islands \& peninsulas

\begin{tabular}{|l|l|l|l|}
\hline $\begin{array}{l}\text { the Sinai Peninsula } \\
\text { the island of Crete } \\
\text { the Peloponnese } \\
\text { the Peloponnesus }\end{array}$ & $\begin{array}{l}\text { the island of Corcyra } \\
\text { the island of Euboea } \\
\text { the island of Salamis } \\
\text { the island of Delos }\end{array}$ & $\begin{array}{l}\text { the island of Samos } \\
\text { the island of Melos } \\
\text { the Italian peninsula }\end{array}$ & $\begin{array}{l}\text { the island of Sicily } \\
\text { the southern peninsula of } \\
\text { Greece } \\
\text { the island of Corsica and } \\
\text { Sardinia }\end{array}$ \\
\hline
\end{tabular}

Others

\begin{tabular}{|l|l|l|l|}
\hline $\begin{array}{l}\text { the Dardanelles } \\
\text { the coast of Attica } \\
\text { the Persian Gulf }\end{array}$ & $\begin{array}{l}\text { the Bering Strait } \\
\text { the Atlantis seaboard }\end{array}$ & $\begin{array}{l}\text { the Judaean desert } \\
\text { the Sinai desert }\end{array}$ & $\begin{array}{l}\text { the Silk Road } \\
\text { the Indian subcontinent } \\
\text { the Asia-North America land } \\
\text { bridge }\end{array}$ \\
\hline
\end{tabular}

The rule that the definite article is used with countries when they include a countable noun applies according to our analysis to the names of empires and kingdoms, as well (the Assyrian Empire, the Akkadian kingdom). When the name of an empire or kingdom does not contain a common noun, the zero article is suggested (Sumer, Upper Egypt). The indefinite article is used only in constructions like to become an Athenian empire, a Persian empire. The use of articles with the names of historical states is based on the above mentioned general principles (the Chaldean state, Han China).

As for the names of cities, towns, and villages, all the analysed lexemes are combined with the zero article, except for the names with of-construction (Uruk, the city of Ebla, the town of Sheckem, the polis of Thebes, the village of Plataea).

The articles preceding the names of valleys (the Indus Valley), mountain ranges (the Taurus Mountains), mountains and hills (Sinai), rivers (the Euphrates), seas (the Aegean) and continents (central Africa) correspond with the generally prescribed rules; the only exception is the Pnyx (mountain).

Concerning the names of deltas, only one instance was found, namely the Mekong delta with the definite article.

Several instances of important buildings and monuments occurred, all with the definite article (the Acropolis, the Wailing Wall, the Great Pyramid, the Tower of Babel).

The names denoting regions are determined in two ways, either with the definite article (the Near East, the Delta, the Levant), or with the zero article (Asia Minor, Nubia, Anatolia). The use of the definite article with the of- construction is obvious (the region of Ionia, the territory of Messenia). It may be assumed that certain geographical names of regions (similarly to the names of moun- tains) penetrate into English in their original form i.e. with the article or not, e.g. Asia Minor taken from Latin.

Based on the general rule the definite article is applied with the names of nationalities and tribes if they refer to nations (or tribes) as a whole (the Semites, the Mesopotamians, the Aztecs). Only two instances with the zero article (not referring to the whole nation) occurred (modern Jews, Celtic peoples known as Gauls).

Concerning the names of peninsulas they are used with the definite article in all the found instances (the Sinai Peninsula, the Peloponnnese). When being a part of the of-construction the names of islands are combined entirely with the definite article (the island of Salamis, the island of Sicily).

The use of articles with other found geographical names of coastline and deserts is based on the general rule, i.e. the definite article is applied (the Atlantis seaboard, the Dardanelles, the coast of Attica, the Judaean desert). The following three non-classified geographical names are accompanied with the definite article (the Asia-North America land bridge, the Indian subcontinent, the Silk Road).

\section{Conclusions}

The analysis of the gathered material shows that general rules for the use of articles with geographical place names are applicable to the names of historical (some of them not existing any more) geographical places, as well. Our aim is to continue in this field of research focusing on further periods of human history, namely the Middle Ages and the New Age in order to cover the use of articles with remaining historical place names.

\section{References:}

[1] ALEXANDER, L. G.: Longman English Grammar, Longman, 1998.

42 - KOMUNIKÁCIE / COMMUNICATIONS 4/2007 
[2] BEAUMONT, D. - GRANGER, C.: The Heinemann ELT English Grammar, Macmillan, 1998.

[3] CHAMBERS, M. - GREW, R. - HERLIHY, D. - RABB, T. K. - WOLOCH, I.: The Western Experience, New York: McGraw - Hill, Inc., 1991.

[4] EASTWOOD, J.: Oxford Guide to English Grammar, OUP, 1994.

[5] EASTWOOD, J.: Oxford Learner's Grammar, Grammar Finder, OUP, 2005.

[6] FOLEY, M., HALL, D.: Advanced Learnerse Grammar, Longman, 2003.

[7] HEWINGS, M.: Advanced Grammar in Use, Cambridge, 2000.

[8] MURPHY, R., SMALZER, W. R.: Grammar in Use Intermediate, CUP, 1989.

[9] QUIRK, R., GREENBAUM, S., LEECH, G., SVARTVIK, J.: A Comprehensive Grammar of the English Language, Longman, 1985.

[10] QUIRK, R., GREENBAUM, S., LEECH, G., SVARTVIK, J.: A Grammar of Contemporary English, Longman, 1984.

[11] QUIRK, R., GREENBAUM, S.: A University Grammar of English, Longman, 1975. 